\title{
Ecotoxicological and pathological studies of common guillemots Uria aalge beached on the Belgian coast during six successive wintering periods (1989-90 to 1994-95)
}

\author{
V. Debacker ${ }^{1, *}$, L. Holsbeek ${ }^{2}$, G. Tapia $^{2}$, S. Gobert ${ }^{1}$, C. R. Joiris ${ }^{2}$, T. Jauniaux ${ }^{3}$, \\ F. Coignoul ${ }^{3}$, J.-M. Bouquegneau ${ }^{1}$
}

\author{
'Oceanology Department, University of Liège, B6 Sart Tilman, B-4000 Liège, Belgium \\ ${ }^{2}$ Laboratory for Ecotoxicology and Polar Ecology, Free University of Brussels (VUB), Pleinlaan 2, B-1050 Brussels, Belgium \\ ${ }^{3}$ Pathology Department of the Veterinary College, University of Liège, B43 Sart Tilman, B-4000 Liège, Belgium
}

\begin{abstract}
During 6 successive wintering periods, 727 common guillemots Uria aalge were recovered from Belgian beaches. One-third of the birds were already dead; the rest passed through rehabilitation centres where they eventually died. All birds were monitored for general condition (body mass, fat reserves), eventual status of oiling and pathological changes (cachexia, acute hemorrhagic gastroenteropathy); 339 birds were sampled for trace metals (total and organıc $\mathrm{Hg}, \mathrm{Cu}, \mathrm{Zn}, \mathrm{Fe}, \mathrm{Cd}$ ) and PCB (polychlorinated biphenyl) analysis. Oiling is still a major cause of death for wintering pelagic seabirds: half of the birds showed signs of external or internal oiling, probably a still greater number of oiled birds never reach the shores. Although a low body mass can be considered a normal. winter condition for wintering guillemots, pathology results showed that three-quarters of the studied animals were in a state of cachexia with emaciated pectoral muscle and lowered muscle lipid content. Elevated levels of $\mathrm{Cu}, \mathrm{Zn}, \mathrm{Hg}$ and PCBs were linked to the state of cachexia and may well represent an additional stress factor leading to the debilitation and death of part of the wintering guillemot population.
\end{abstract}

KEY WORDS: Heavy metals PCBs Cachexia Guillemots Belgian coast

\section{INTRODUCTION}

Although a relatively small ecosystem, the North Sea is known for its high fish productivity and catches. However, oil refineries, steelworks, metallurgy, chemical and paper industries form a dense network in the adjacent countries with subsequent busy shipping routes. During the past few decades, offshore gas and oil industries have developed rapidly.

To assess the human impact on this complex ecosystem, the Belgian authorities, within the frame of the 3rd European North Sea Conference, promoted a programme to monitor the health and causes of death of seabirds and marine mammals. Emphasis was placed

•E-mail: s911634@student.ulg.ac.be particularly on seabirds, which are found dead or dying on beaches in far larger numbers than are marine mammals. With a population of about 10 million wintering birds, the North Sea is one of the world's major areas for sea, shore and water birds (Birkhead 1974, Mead 1974, Bourne \& Vauk 1988, Dunnet et al. 1990, North Sea Task Force Report 1993a, b). Pelagic species - petrels, auks and gannets-are particularly sensitive to ecosystem alteration such as depletion of fish stocks, oil spills, breeding site destruction, and chronic or acute organochlorine and heavy metals pollution (Bourne \& Vauk 1988, Dunnet et al. 1990, Carter et al. 1993). In particular, oiling is known to be a severe threat to wintering seabirds (Mead \& Baillie 1981, Stowe \& Underwood 1984, Camphuysen \& van Franeker 1992, Carter et al. 1993, Dahlmann et al. 1994). The common guillemot Uria aalge outnumbers 
by far all other wintering species. As a consequence, it became the focus of this study.

Seabird mortality and, in particular, winter strandings have been carefully reported and monitored along the Belgian coast (Kuyken 1978) and coasts of the neighbouring countries (e.g. Camphuysen \& van Franeker 1992). Camphuysen \& Leopold (1994) estimated the number of wintering guillemots in the $130000 \mathrm{~km}^{2}$ southern North Sea area at about 235000 individuals for the 1984 and 1987 October-November peak period. A decline in density occurs around February-March as the birds move back towards the breeding grounds. To what extent birds dying at sea contribute to this decline is unclear, as the percentage of these birds finally reaching the shores is unknown.

Seabirds are likely candidates to accumulate toxic pollutants (organochlorines and heavy metals) and have been widely used as bioindicators (Muirhead \& Furness 1988, Ohlendorf \& Fleming 1988, Thompson 1990, Walsh 1990, Elliot et al. 1992, Thompson et al. 1992, Stewart et al. 1994, Burger \& Gochfeld 1995, Wenzel \& Gabrielsen 1995). Long-term chronic effects of contaminants may have severe consequences on reproduction, disease, stress susceptibility (immunosuppression) and behaviour patterns (Scheuhammer 1987. Peakall 1992). Despite extensive information on heavy metal and organochlorine levels in seabirds, few papers have considered the possible links to pathological findings. The aim of this paper is to combine ecotoxicological data and the most severe pathological ones (cachexia, acute and hemorrhagic gastroenteropathy) in order to evaluate the possible causes of death of wintering common guillemots. Preliminary results concerning the mean heavy metal content of the birds collected between 1990 and 1993 suggested high levels of $\mathrm{Cu}_{1} \mathrm{Zn}$ and $\mathrm{Hg}$ (Bouquegneau et al. 1994).

\section{MATERIAL AND METHODS}

Collection and storage. A regular and systematic collection of stranded seabirds was organised along the $67 \mathrm{~km}$ of the Belgian shore during 6 successive winters (1989-90 to 1994-95). A total of 251 dead guillemots were collected from the beaches; an additional 476 live guillemots were collected and went through rehabilitation centres where they eventually died. Putrified specimens were discarded. Collected carcasses were kept frozen until necropsy was performed at the Pathology Department of the Veterinary College, Liège University, using a consistent protocol (Dorrestein \& van der Hage 1993). They were weighed, and oil contamination on plumage and/or in intestinal tract and lesions were noted. Nutritional state, absence of subcutaneous fat, and light to severe atrophy of pectoral muscle (visible signs of cachexia) were evaluated on a range from 0 to 3 ; specifically: 0 , presence of subcutaneous fat, normal pectoral muscle; 1 , absence of fat and slight pectoral muscle atrophy; 2 , moderate pectoral muscle atrophy; 3 , severe pectoral muscle atrophy. For statistical purposes, group 0 was tested against groups 1,2 , and 3 to compare normal versus cachectic birds. Necropsy technique involved opening of body cavities, dissection of the digestive tract, and examination of the respiratory, urinary and genital systems (Jauniaux et al. 1996). Intestinal serosal surface congestion, hyperaemic and thickened intestinal wall, and hemorrhagic content were used as parameters for acute and hemorrhagic gastro-enteropathy diagnosis (Dorrestein \& van der Hage 1997). Parasites were identified on 248 guillemots and have been previously reported by Brosens et al. (1996). Respiratory tract mycetes (Aspergillus spp.) have been identified on 7 guillemots out of 198 (Jauniaux \& Coignoul 1994). For bacteriology, all 727 birds were evaluated for evidence of intestinal salmonellosis following a classic isolation procedure reported elsewhere (Jauniaux et al. 1996). Three birds were positive for Salmonella (2 cases of $S$. enteritidis and 1 case of undetermined Salmonella spp.). Histopathology was restricted to lesions observed at necropsy. Most lesions were histolytic and bore freezing artifacts. The only significant lesions seen in guillemots were in relation with infectious agents such as Aspergillus spp. (see above). No test was used for virus isolation. Two age classes were considered based on the presence of cloacal bursa fabricii (Camphuysen \& van Franeker 1992): class I comprising juvenile (1st winter) and immature (2nd and 3rd winter) birds; class II (4th winter and thereafter), consisting of mature but not necessarily breeding birds. Of a total of 727 birds, 339 (170 beached dead, 169 from rehabilitation centres) were dissected and samples of liver, kidney and pectoral muscle were collected for analysis of total $\mathrm{Hg}$, organic $\mathrm{Hg}$, polar lipids and PCBs (Laboratory for Ecotoxicology and Polar Ecology of Brussels Free University) and heavy metals, metallothioneins and total lipids (Oceanology Department of Liège University).

Total mercury and organic mercury analyses. Total mercury analyses were performed by specific atomic absorption spectrometry using a Perkin-Elmer MAS-50 Mercury analyser after the method described by Hatch \& Ott (1968), modified by Bouquegneau (1973).

Organic mercury (MeHg) concentrations were measured by ECD semi-capillary gas chromatography on a Packard 437 following a toluene (Merck 8389) 3-step extraction (Uthe et al. 1972). Fresh weight/dry weight ratio was determined by lyophilising. Mercury concentrations were expressed as $\mu \mathrm{g} \mathrm{g}^{-1}$ dry weight (DW). 
Quality control measurements for both total and organic mercury included replicate analysis resulting in coefficients of variation $<10 \%$ and analysis of certified reference material (DORM-1, NRC, Canada) with a variation in the measurement up to $10 \%$ at the most. Limits of detection were $0.01 \mathrm{\mu g}$ and $0.02 \mathrm{ng}$ respectively, corresponding to 0.01 and $0.02 \mathrm{\mu g} \mathrm{g}^{-1} \mathrm{DW}$ for an average $1 \mathrm{~g}$ sample

Other trace element analysis. Atomic absorption spectrophotometry (ARL 3510) was used to determine heavy metal concentrations ( $\mathrm{Cu}, \mathrm{Zn}, \mathrm{Cd}, \mathrm{Fe}) . \mathrm{Pb}, \mathrm{Ni}, \mathrm{Cr}$ and $\mathrm{Ti}$ contents were also determined but the results most often were below the detection limits and will not be discussed. After being weighed and dried for $48 \mathrm{~h}$ at $110^{\circ} \mathrm{C}$, samples were digested with a mixed solution of chloric (Merck 317) and nitric (Merck 456) acids (1:3, $\mathrm{v}: \mathrm{v})$ and slowly heated to $100^{\circ} \mathrm{C}$ until complete digestion. The samples were then diluted, filtered and analysed. Parallel to the samples, a set of certified material samples (CRM 278 Community Bureau of Reference, Commission of the European Communities) was also analysed to ensure the method's sensitivity. Recoveries ranged from 92 to $102 \%$ for $\mathrm{Cu}, \mathrm{Zn}$ and $\mathrm{Fe}$ and $80 \%$ for $\mathrm{Cd}$. Limits of detection were $0.01 \mathrm{\mu g} \mathrm{g}^{-1}$ DW for $\mathrm{Cu}, 0.33$ for $\mathrm{Zn}$ and 0.22 for $\mathrm{Cd}$. Concentrations are expressed as $\mu \mathrm{g} \mathrm{g}^{-1} \mathrm{DW}$

PCB analysis. PCB (polychlorinated biphenyl) residues were determined by ECD-gas chromatography on a Shimadzu GC14A using a $30 \mathrm{~m}$ fused silica CPSil $8 \mathrm{CB}$ capillary column following a hexane extraction (Jansen 26.836.64) and florisil (Macherey-Nagel 81571) clean-up. PCBs were identified using a congener mixture including International Union of Pure and Applied Chemistry (IUPAC) congeners 28, 52, 101, 118, 138, $153,156,170,180$ and 194. Results were expressed as $\mu \mathrm{g} \mathrm{g}^{-1}$ DW. Since the sample PCB patterns did not sufficiently coincide with Aroclor 1254 or 1260 patterns, results were expressed as $\Sigma$ PCB, or the sum of the 10 individually identified congeners, which represents $\pm 35 \%$ of the total PCB load.

Sample preparation and lipids analysis. The method used for the total lipids extraction was described by Barnes \& Blackstock (1973). The polar lipid content was determined gravimetrically after lipid hexane extraction included in the PCB procedure. Total and polar lipids are expressed as $\mathrm{g} \mathrm{g}^{-1} \mathrm{DW}$.

Statistical analysis. All statistical tests were performed using Statistica ${ }^{(3)}$ for Windows 5.1 computer programme. Tissue concentrations for each metal were tested to fit a normal distribution using KolmogorovSmirnov 1-sample tests. In the case of normal distribution, data were analysed using a $t$-test. When data significantly differed from a normal distribution, a nonparametric test (Mann-Whitney $U$-test) was used. Differences were considered significant when $p<0.01$.

\section{RESULTS AND DISCUSSION}

None of the birds recovered in the present study were ringed, so that no information was available on their origin and/or their wanderings prior to death This situation most probably reflects the fact that only a small proportion of birds are ringed and that not all dying birds are washed ashore (Pionneau 1987, Camphuysen \& van Franeker 1992). Nevertheless, a small number of ringed guillemots $(n=27)$ found in Belgium during the 1980s and 1990s were mainly of Scottish origin (17/27); only a minor fraction came from Germany, Sweden, The Netherlands, the South of England and Ireland ( $W$. Roggeman pers. comm.). Recoveries of guillemots during the 1980s in The Netherlands revealed that a majority of birds had been ringed in Scotland (Camphuysen \& van Franeker 1992). With a necessary word of caution based on the fact that ringing efforts are not the same in all countries, it still seems reasonable to assume that most of the guillemots collected during the past 6 yr originated from the Scottish area. Several studies show that guillemots have no clear migration pattern, but rather disperse at sea, and that immature individuals are likely to show a higher mortality rate than adult birds (Birkhead 1974. Mead 1974, Nettleship \& Evans 1985, Lloyd et al. 1991) Both Landsborough (1953) and Mead (1974) showed that guillemots ringed at colonies on the eastern coasts of England and Scotland had moved through the English Channel and the southern part of the North Sea. Aerial and ship surveys in the southern North Sea clearly indicate that large numbers of guillemots enter this area by October-November and move out again by February-March (Camphuysen \& Leopold 1994).

A sample of 339 guillemots was fully investigated. During the 6 winters included in the study period, $89 \%$ of the birds were collected from January to March (Fig. 1). Peak densities (number of guillemots per $\mathrm{km}^{2}$ sea surface) in the southern North Sea were recorded from October to January (Camphuysen \& Leopold 1994). High densities, probably combined with severe environmental constraints such as low temperatures, storms and starvation, provoke an important mortality during the second half of the wintering period. A large proportion of the birds were oiled, either externally or both externally and internally, or showed clear signs of exhaustion, with emaciated pectoral muscle and very little or absence of abdominal and subcutaneous fat, 2 distinctive features of cachexia, a long and chronic condition (Table 1).

Significant differences appeared for $\mathrm{Zn}, \mathrm{Fe}$, total $\mathrm{Hg}$, organic $\mathrm{Hg}$ and PCBs between dead birds from the beach and those provided by rehabilitation centres (Table 2). These high levels of pollutants in rehabili- 


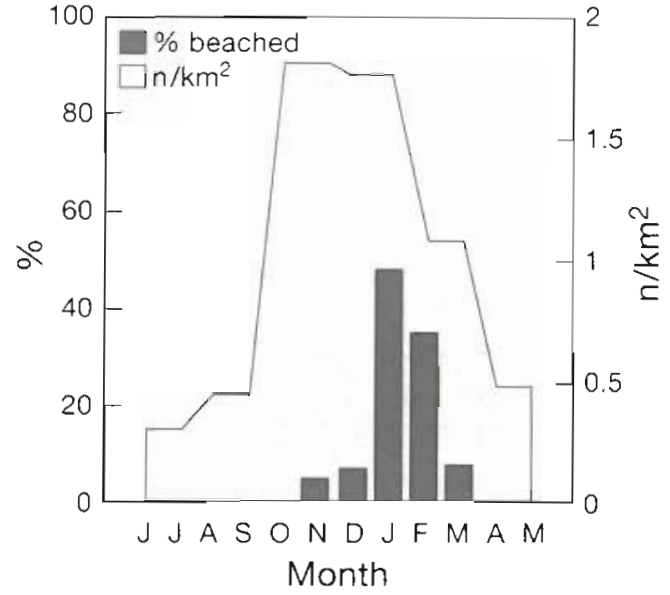

Fig. 1 Uria aalge. Overall stranding (percentage of total number) of guillemots ( $\square$, this work) compared to their densities ( $\square$, number per $\mathrm{km}^{2}$; Camphuysen \& Leopold 1994) in the southern North Sea

tated birds are not likely to result from a decrease of body mass but probably instead from dietary changes. [This is indeed confirmed by the fact that $\delta^{13} \mathrm{C}$ content of the tissues was lower in rehabilitated guillemots $(\mathrm{S}$. Caulle, P. Dauby \& V. Debacker unpubl. results).] For this reason, from the third winter on, we decided to focus only on individuals found dead, considering that birds that passed through rehabilitation centres could be an important bias. The following discussion therefore only refers to individuals washed ashore dead. Nevertheless, this sample is not necessarily fully representative of the 'natural' population.
Most of the birds were oiled $(55 \%)$ and cachectic $(76 \%)$ (Table 1). Sixty-one percent had developed acute hemorrhagic gastro-enteropathy. Thirty-one percent were oiled externally and internally; $24 \%$ showed only external traces; $45 \%$ showed no signs of oiling. Oiling is known to be a major cause of death for wintering guillemots entering the fairly polluted southern North Sea (Stowe \& Underwood 1984, Camphuysen \& Leopold 1994, Dahlmann et al. 1994, Camphuysen 1995). Partial or extensive oiling necessarily leads to starvation, debilitation and subsequent death, and eventual stranding.

We systematically examined the influence of age, sex, the most frequent lesions (cachexia, acute hemorrhagic gastro-enteropathy), and stable pollutant levels (heavy metals and PCBs) on the contamination levels of the tissues (Table 3). No clear-cut differences appeared between class I (juvenile and immature) versus class II (adult) birds, nor between male and female birds, except for cadmium concentrations which were twice as high in adult kidney $(p<0.01)$. The 2 groups displayed median $\mathrm{Cd}$ concentrations of 4.9 and $9.2 \mu \mathrm{g}$ $\mathrm{g}^{-1} \mathrm{DW}$, with different distribution patterns for age class I and class II (Fig. 2). Variations in kidney $\mathrm{Cd}$ levels are likely to reflect both dietary differences and age accumulation effects. Cd concentrations in the kidney has been shown to correlate with age in several seabird species (Thompson 1990, Lock et al. 1992).

One might expect a general increase of pollutant levels in the case of cachexia. Apart from a general decrease of subcutaneous fat, the total weight loss in the case of cachectic birds $(708 \pm 116 \mathrm{~g}$, non-cachectic $781 \pm 140 \mathrm{~g})$ was linked to a general decrease in

Table 1. Unia aalge. Percentages of class I (juvenile and immature) and class II (adult), male and female, non-cachectic (-) and cachectic $(+)$, acute hemorrhagic gastro-enteropathy negative $(-)$ and positive $(+)$, oiling: no oiling, external only (E) and external and internal oiling $(E+I)$, of guillemots collected either directly from the beach (Beached) or after a stay in a rehabilitation centre (Centre)

\begin{tabular}{|c|c|c|c|c|c|c|c|c|c|c|c|c|}
\hline & \multirow[t]{2}{*}{$\mathrm{n}$} & \multirow{2}{*}{$\begin{array}{l}\text { Age class I } \\
\text { Juv. + imm. }\end{array}$} & \multirow{2}{*}{$\begin{array}{l}\text { Age class II } \\
\text { Adult }\end{array}$} & \multirow{2}{*}{\multicolumn{2}{|c|}{$\begin{array}{c}\text { Sex } \\
\text { Male Female }\end{array}$}} & \multicolumn{2}{|c|}{ Cachexia } & \multicolumn{2}{|c|}{ Gastro-enteropathy } & \multicolumn{3}{|c|}{ Oiling } \\
\hline & & & & & & - & + & - & + & No & E & $E+I$ \\
\hline \multicolumn{13}{|l|}{ Beached } \\
\hline Winter 1989-90 & 48 & 77 & 23 & 62 & 38 & 23 & 77 & 54 & 46 & 0 & 11 & 89 \\
\hline Winter 1990-91 & 31 & 45 & 55 & 60 & 40 & 18 & 82 & 54 & 46 & 9 & 0 & 91 \\
\hline Winter 1991-92 & 12 & 67 & 33 & 42 & 58 & 30 & 70 & 60 & 40 & 33 & 0 & 67 \\
\hline Winter 1992-93 & 75 & 54 & 46 & 49 & 51 & 12 & 88 & 34 & 66 & 56 & 24 & 20 \\
\hline Winter 1993-94 & 74 & 70 & 30 & 57 & 43 & 30 & 70 & 36 & 64 & 63 & 31 & 6 \\
\hline Winter 1994-95 & 11 & 70 & 30 & 80 & 20 & 27 & 73 & 9 & 91 & 36 & 67 & 0 \\
\hline All & 251 & 65 & 35 & 56 & 44 & 24 & 76 & 39 & 61 & 45 & 24 & 31 \\
\hline \multicolumn{13}{|l|}{ Centre } \\
\hline Winter 1989-90 & 83 & 67 & 33 & 69 & 31 & 13 & 87 & 58 & 42 & 0 & 31 & 69 \\
\hline Winter 1990-91 & 122 & 63 & 38 & 50 & 50 & 40 & 60 & 52 & 48 & 0 & 12 & 88 \\
\hline Winter $1991-92$ & 64 & 83 & 17 & 65 & 35 & 37 & 63 & 60 & 40 & 12 & 23 & 65 \\
\hline Winter 1992-93 & 116 & 81 & 19 & 50 & 50 & 9 & 91 & 43 & 57 & 34 & 20 & 45 \\
\hline Winter 1993-94 & 76 & 67 & 33 & 63 & 37 & 18 & 82 & 43 & 57 & 49 & 42 & 4 \\
\hline Winter 1994-95 & 15 & 60 & 40 & 64 & 36 & 40 & 60 & 47 & 53 & 53 & 47 & 0 \\
\hline All & 476 & 75 & 25 & 61 & 39 & 26 & 74 & 55 & 45 & 13 & 23 & 64 \\
\hline
\end{tabular}


Table 2. Uria aalge. Body mass $(\mathrm{g})$ and trace elements concentrations ( $\mu \mathrm{g} \mathrm{g}^{-1} \mathrm{DW}$ ) in liver, kidney and muscle of guillemots, collected either directly from the beach (Beach) or after a stay in a rehabilitation centre (Centre), expressed as a mean \pm standard deviation, median, range of concentrations (minimum - maximum), and number of samples ( $n$ ); nd: non determined, <dl: below detection limit, ns: not significant. Total and polar lipids are expressed as $\mathrm{g} \mathrm{g}^{-1} \mathrm{DW}$. Statisitical significant differences at $\mathrm{p}<0.01$ are given in bold

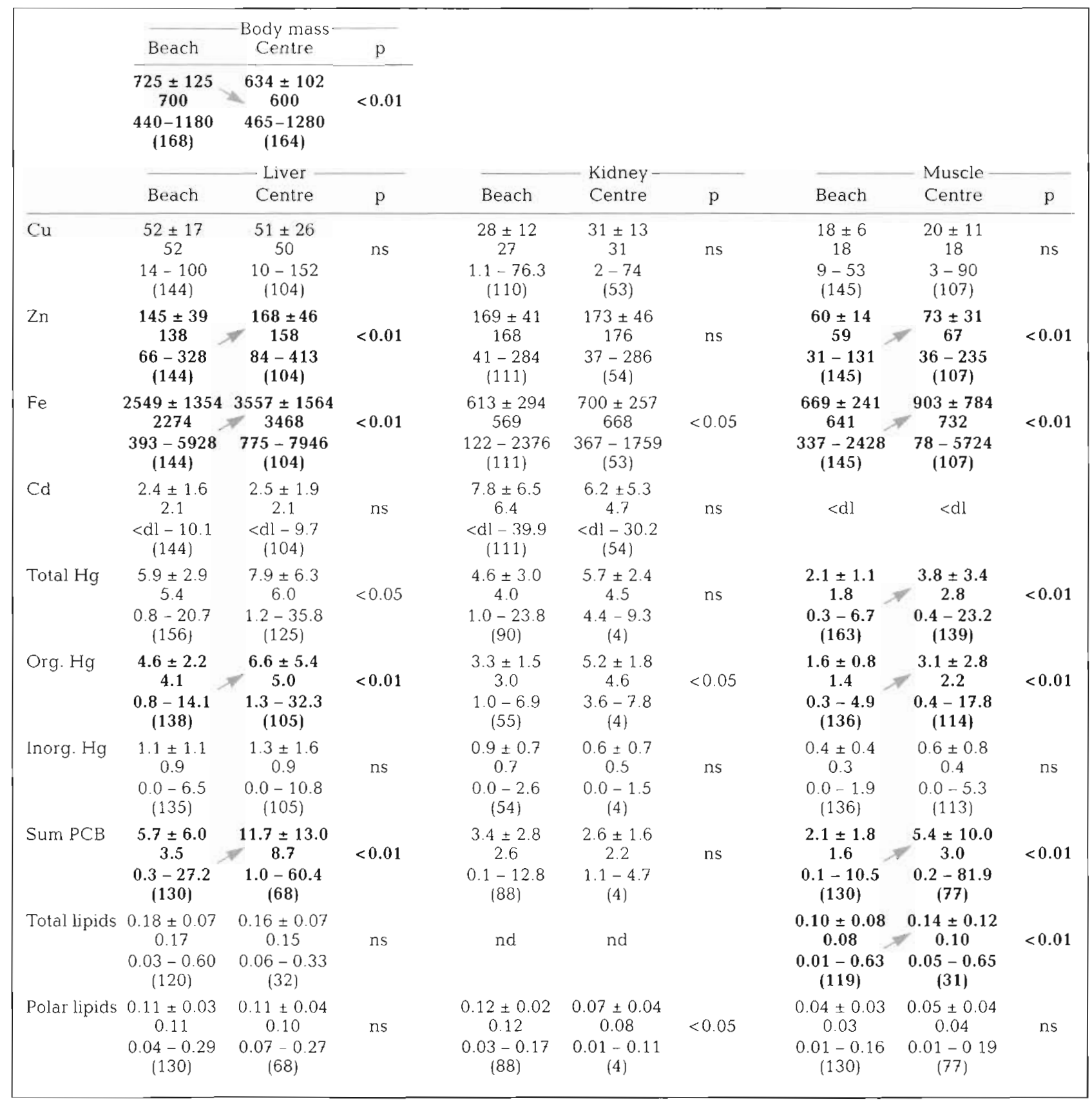

muscle lipid content. Elevated liver levels for PCBs in the case of cachectic birds might indicate a remobilization after depletion of fat deposits (Fig. 3). It is also worth noting that the highest levels for PCBs, particularly in the liver, were always found in cachectic animals. For all tissues, significantly higher levels of $\mathrm{Zn}_{\mathrm{n}}$ were also linked to the status of cachexia.
Acute hemorrhagic gastro-enteropathy showed no clear relation with levels of stable contaminants, except in the case of organic $\mathrm{Hg}$, which was found in higher concentrations in the kidney of animals which had developed acute hemorrhagic gastro-enteropathy (Table 3b). The inflammatory nature of the intestinal lesion could not be conclusively assessed, due to the 
Table 3. Uria aalge. Body mass (g) and trace elements concentrations ( $\mu \mathrm{g} \mathrm{g}^{-1} \mathrm{DW}$ ) in (a) liver, (b) kidney and (c) muscle of guillemots expressed as a mean \pm standard deviation, median and number of samples ( $n$ ) in individuals found dead on the shores ( $n=170$ ): class I (juvenile and immature) and class II (adult), male and female, non-cachectic (-) and cachectic (+), acute hemorrhagic gastro-enteropathy negative (-) and positive $(+)$, oiling: no oiling, external and internal oiling $(E+l)$ and external only $(E)$. Total and polar lipid content expressed as $g g^{-1} D W$. Statisitical significant differences at $\mathrm{p}<0.01$ are given in bold

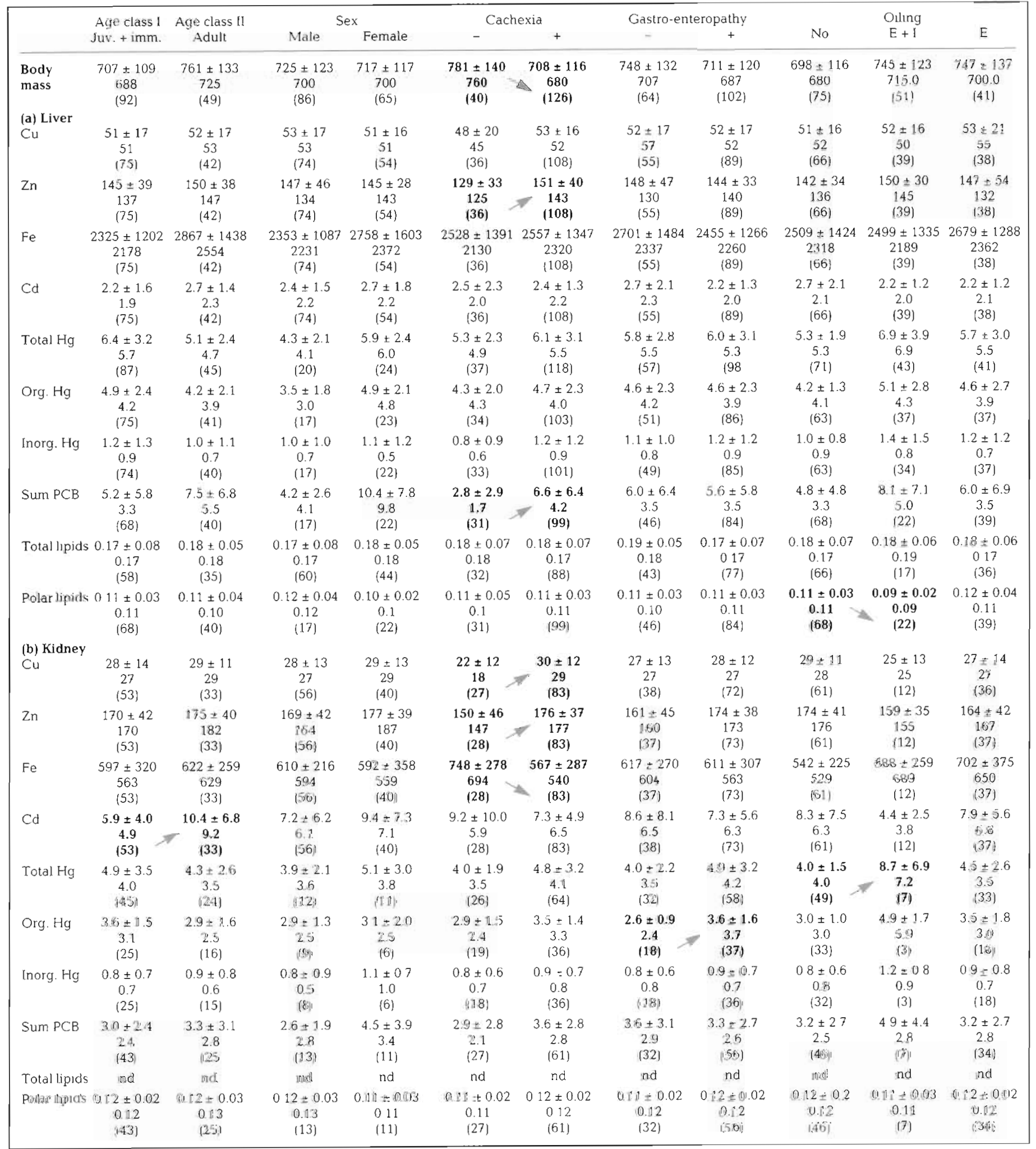


Table 3 (continued)

\begin{tabular}{|c|c|c|c|c|c|c|c|c|c|c|c|}
\hline & \multirow{2}{*}{$\begin{array}{l}\text { Age class I } \\
\text { Juv. + imm. }\end{array}$} & \multirow{2}{*}{$\begin{array}{l}\text { Age class II } \\
\text { Adult }\end{array}$} & \multicolumn{2}{|c|}{ Sex } & \multicolumn{2}{|c|}{ Cachexia } & \multicolumn{2}{|c|}{ Gastro-enteropathy } & \multicolumn{3}{|c|}{ Oiling } \\
\hline & & & Male & Female & - & + & - & + & No & $E+I$ & E \\
\hline $\begin{array}{l}\text { (c) Muscle } \\
\mathrm{Cu}\end{array}$ & $\begin{array}{c}18 \pm 6 \\
18 \\
(77)\end{array}$ & $\begin{array}{c}16 \pm 4 \\
16 \\
(41)\end{array}$ & $\begin{array}{c}18 \pm 6 \\
18 \\
(76)\end{array}$ & $\begin{array}{c}18 \pm 5 \\
17 \\
(53)\end{array}$ & $\begin{array}{c}18 \pm 5 \\
18 \\
(37)\end{array}$ & $\begin{array}{c}18=6 \\
18 \\
(108)\end{array}$ & $\begin{array}{l}17 \pm 5 \\
17 \\
156)\end{array}$ & $\begin{array}{c}19 \pm 6 \\
18 \\
189 j\end{array}$ & $\begin{array}{c}20 \pm 7 \\
19 \\
(65)\end{array}$ & $\begin{array}{c}16 \pm 4 \\
16 \\
(41)\end{array}$ & $\begin{array}{c}18 \div 5 \\
18 \\
(38)\end{array}$ \\
\hline $\mathrm{Zn}$ & $\begin{array}{c}61 \pm 15 \\
59 \\
(77)\end{array}$ & $\begin{array}{c}58 \pm 11 \\
57 \\
(41)\end{array}$ & $\begin{array}{c}58 \pm 16 \\
55 \\
767\end{array}$ & $\begin{array}{c}61 \pm 11 \\
61 \\
153 \mid\end{array}$ & $\begin{array}{c}53 \pm 12 \\
52 \\
(37)\end{array}$ & $\begin{array}{c}62 \pm 14 \\
62 \\
(108)\end{array}$ & $\begin{array}{c}57 \pm 13 \\
55 \\
(56)\end{array}$ & $\begin{array}{c}62 \pm 15 \\
61 \\
{[89]}\end{array}$ & $\begin{array}{c}63 \pm 15 \\
63 \\
(65)\end{array}$ & $\begin{array}{c}56 \pm 11 \\
54 \\
(41)\end{array}$ & $\begin{array}{c}59 \pm 15 \\
55 \\
(38)\end{array}$ \\
\hline Fe & $\begin{array}{c}693=292 \\
643 \\
(77)\end{array}$ & $\begin{array}{c}612 \pm 130 \\
584 \\
(41)\end{array}$ & $\begin{array}{c}688 \pm 297 \\
641 \\
(76)\end{array}$ & $\begin{array}{c}649: \pm 131 \\
640 \\
(53)\end{array}$ & $\begin{array}{c}586 \pm 145 \\
580 \\
(37)\end{array}$ & $\begin{array}{c}697 \pm 260 \\
645 \\
(108)\end{array}$ & $\begin{array}{c}646 \pm 238 \\
599 \\
(56)\end{array}$ & $\begin{array}{c}683 \pm 242 \\
663 \\
(89)\end{array}$ & $\begin{array}{c}711 \pm 264 \\
663 \\
(65)\end{array}$ & $\begin{array}{c}601 \pm 107 \\
586 \\
(41)\end{array}$ & $\begin{array}{c}674=289 \\
648 \\
(38)\end{array}$ \\
\hline $\mathrm{Cd}$ & $<\mathrm{dl}$ & $<\mathrm{dl}$ & $<\mathrm{dl}$ & $<\mathrm{dl}$ & $<\mathrm{dl}$ & $<\mathrm{dl}$ & $<\mathrm{dl}$ & $<\mathrm{dl}$ & $<\mathrm{dl}$ & $<\mathrm{dl}$ & $<\mathrm{dl}$ \\
\hline Total $\mathrm{Hg}$ & $\begin{array}{c}2.2 \pm 11 \\
1.9 \\
(89)\end{array}$ & $\begin{array}{c}2.0 \pm 1.2 \\
1.7 \\
(49)\end{array}$ & $\begin{array}{c}1.6 \pm 0.9 \\
1.4 \\
(20)\end{array}$ & $\begin{array}{c}2.3 \pm 1.4 \\
1.9 \\
(28)\end{array}$ & $\begin{array}{c}2.0 \pm 0.8 \\
2.1 \\
(39)\end{array}$ & $\begin{array}{c}2.1 \pm 1.2 \\
1.7 \\
(122)\end{array}$ & $\begin{array}{c}2.2 \pm 1.3 \\
2.0 \\
(62)\end{array}$ & $\begin{array}{c}2.0 \pm 1.0 \\
17 \\
(99)\end{array}$ & $\begin{array}{c}1.9 \pm 0.8 \\
1.8 \\
(72)\end{array}$ & $\begin{array}{c}2.5 \pm 1.3 \\
2.3 \\
(49)\end{array}$ & $\begin{array}{c}2.0 \pm 1.3 \\
1.5 \\
(41)\end{array}$ \\
\hline Org. $\mathrm{Hg}$ & $\begin{array}{c}1.7 \pm 0.8 \\
1.6 \\
(77)\end{array}$ & $\begin{array}{c}1.5 \pm 0.9 \\
1.3 \\
(39)\end{array}$ & $\begin{array}{c}1.2 \pm 0.8 \\
1.0 \\
(15)\end{array}$ & $\begin{array}{c}1.7 \pm 0.9 \\
1.4 \\
(23)\end{array}$ & $\begin{array}{c}1.5 \pm 0.7 \\
1.5 \\
(33)\end{array}$ & $\begin{array}{c}1.7 \pm 0.9 \\
1.4 \\
(101)\end{array}$ & $\begin{array}{c}17 \pm 1.0 \\
1.4 \\
(49)\end{array}$ & $\begin{array}{c}1.6 \pm 0.8 \\
1.4 \\
(85)\end{array}$ & $\begin{array}{c}1.5 \pm 0.6 \\
1.4 \\
(64)\end{array}$ & $\begin{array}{c}1.8 \pm 0.9 \\
1.5 \\
(35)\end{array}$ & $\begin{array}{c}1.6 \pm 1.1 \\
1.3 \\
(36)\end{array}$ \\
\hline Inorg. $\mathrm{Hg}$ & $\begin{array}{c}0.4 \pm 0.4 \\
0.3 \\
\{77\}\end{array}$ & $\begin{array}{c}0.4 \pm 0.4 \\
0.2 \\
(39)\end{array}$ & $\begin{array}{c}0.3 \pm 0.3 \\
0.2 \\
(15)\end{array}$ & $\begin{array}{c}0.4 \pm 0.5 \\
0.3 \\
(23)\end{array}$ & $\begin{array}{c}0.4 \pm 0.4 \\
0.3 \\
(33)\end{array}$ & $\begin{array}{c}0.4 \pm 0.4 \\
0.3 \\
(101)\end{array}$ & $\begin{array}{c}04 \pm 0.4 \\
0.3 \\
(49)\end{array}$ & $\begin{array}{c}0.4 \pm 0.4 \\
0.3 \\
(85)\end{array}$ & $\begin{array}{c}0.3 \pm 0.4 \\
0.2 \\
(64)\end{array}$ & $\begin{array}{c}0.6 \pm 0.4 \\
0.5 \\
(35)\end{array}$ & $\begin{array}{c}0.3 \pm 0.4 \\
0.2 \\
(36)\end{array}$ \\
\hline Sum PCB & $\begin{array}{c}1.8 \pm 1.4 \\
1.3 \\
(68)\end{array}$ & $\begin{array}{c}2.6 \pm 2.1 \\
2.1 \\
(40)\end{array}$ & $\begin{array}{c}1.9 \pm 0.9 \\
1.6 \\
(17)\end{array}$ & $\begin{array}{c}3.1 \pm 2.5 \\
2.5 \\
(22)\end{array}$ & $\begin{array}{c}2.5 \pm 2.3 \\
2.0 \\
(31)\end{array}$ & $\begin{array}{c}2.0 \pm 1.5 \\
1.6 \\
(99)\end{array}$ & $\begin{array}{c}2.4 \pm 1.9 \\
1.9 \\
(46)\end{array}$ & $\begin{array}{c}2.0 \pm 1.7 \\
1.6 \\
(84)\end{array}$ & $\begin{array}{c}1.7 \pm 14 \\
1.3 \\
(68)\end{array}$ & $\begin{array}{c}2.9 \pm 2.5 \\
2.0 \\
(22)\end{array}$ & $\begin{array}{c}2.4 \pm 1.7 \\
2.0 \\
(39)\end{array}$ \\
\hline Total lipids & $\begin{array}{c}50.08 \pm 0.04 \\
0.08 \\
(59)\end{array}$ & $\begin{array}{c}0.11 \neq 0.08 \\
0.08 \\
(33)\end{array}$ & $\begin{array}{c}011 \pm 0.09 \\
0.08 \\
(61)\end{array}$ & $\begin{array}{c}0.09 \pm 0.05 \\
0.08 \\
(42)\end{array}$ & $\begin{array}{c}0.13 \pm 0.11 \\
0.11 \\
(32)\end{array}$ & $\begin{array}{c}0.09 \pm 0.05 \\
0.08 \\
(87)\end{array}$ & $\begin{array}{c}0.12 \pm 0.11 \\
0.08 \\
(43)\end{array}$ & $\begin{array}{c}0.09 \pm 004 \\
0.08 \\
(76)\end{array}$ & $\begin{array}{c}009 \pm 0.05 \\
0.08 \\
(65)\end{array}$ & $\begin{array}{c}0.09 \pm 0.05 \\
0.07 \\
(17)\end{array}$ & $\begin{array}{c}0.13 \pm 011 \\
0.10 \\
(36)\end{array}$ \\
\hline Polar lipids & $\begin{array}{c}\mathrm{s} 0.04 \pm 0.02 \\
0.03 \\
(68)\end{array}$ & $\begin{array}{c}0.05 \neq 0.04 \\
0.04 \\
40)\end{array}$ & $\begin{array}{c}0.06 \pm 0.033 \\
0.04 \\
(17)\end{array}$ & $\begin{array}{c}0.04 \pm 0.03 \\
0.03 \\
(22)\end{array}$ & $\begin{array}{c}0.07 \pm 0.04 \\
0.05 \\
(31)\end{array}$ & $\begin{array}{c}0.04 \pm 0.01 \\
0.03 \\
(99)\end{array}$ & $\begin{array}{c}0.05 \pm 0.04 \\
0.04 \\
(46)\end{array}$ & $\begin{array}{c}0.04 \pm 0.02 \\
0.03 \\
(84)\end{array}$ & $\begin{array}{c}003 \pm 0.01 \\
0.03 \\
(68)\end{array}$ & $\begin{array}{c}0.05 \pm 0.03 \\
0.04 \\
(22)\end{array}$ & $\begin{array}{c}0.05 \pm 0.04 \\
0.04 \\
(39)\end{array}$ \\
\hline
\end{tabular}

poor quality of the material for histopathology. However, we felt the lesion was worth mentioning, since it affected $61 \%$ of the birds and had no clear correlation with decay. Previous reports mentioned a hemorrhagic gastro-enteritis as a terminal lesion, related to stress, in marine birds (Dorrestein \& van der Hage 1993, Leighton 1993). In addition, parasitological and bacteriological examinations failed to isolate a likely infectious cause for that lesion (Jauniaux \& Coignoul 1994,

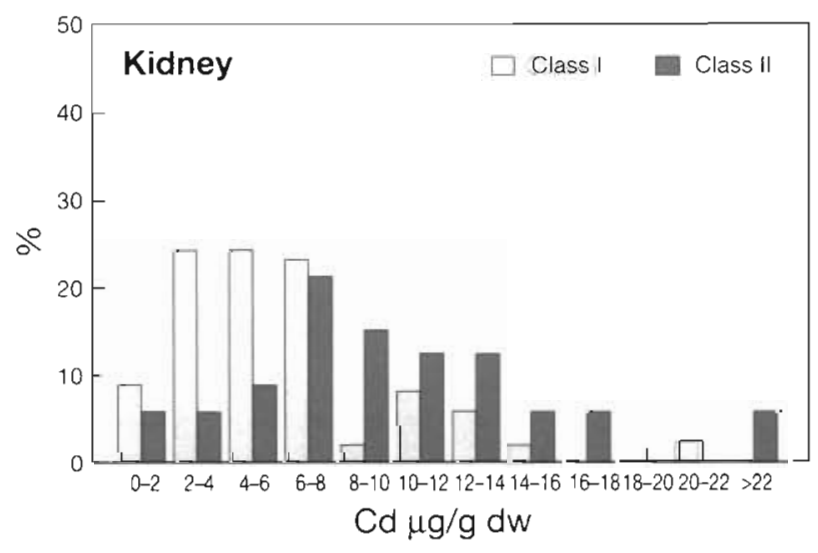

Fig. 2. Uria aalge. Relative distribution of Cd concentration for age class I (juvenile and immature) and age class II (adult) in kidneys of guillemots found dead on the Belgian coast
Brosens et al. 1996, Jauniaux et al. 1996). No significant overall trend could be linked to oiling status when comparing non-oiled and externally oiled birds, which could partially be explained by the fact that external oiling may have occurred as a postmortem artifact. However, significant differences in metal content appeared at different levels in comparisons of non-oiled guillemots with individuals which were oiled both externally and internally; it is still unclear whether or not these differences can be linked to changes in the metabolism of the metals involved in response to oiling.

Compared to guillemots captured in the northern Norway area (Wenzel \& Gabrielsen 1995) and to those shot in northwest Scotland (Stewart et al. 1994), the individuals collected on the Belgian coast were heavily contaminated with $\mathrm{Cu}, \mathrm{Zn}$ and $\mathrm{Hg}$ (Table 4). Similarly high $\mathrm{Cu}$ and $\mathrm{Zn}$ levels for Uria aalge and for other species from the Belgian coast (Larus ridibundus, Rissa tridactyla, Melanitta nigra) were described by Antoine et al. (1992) and Bouquegneau et al. (1994). Moreover, a previous study on the speciation of metals in the cytosol of the liver and kidney of $U$. aalge stranded along the Belgian coast showed that the birds failed to maintain constant $\mathrm{Cu}, \mathrm{Zn}$ and $\mathrm{Cd}$ levels in the high molecular weight soluble proteins in both organs; only a small part of the excess metal was found to be detoxified by metallothioneins (Bouquegneau et al. 1996). 

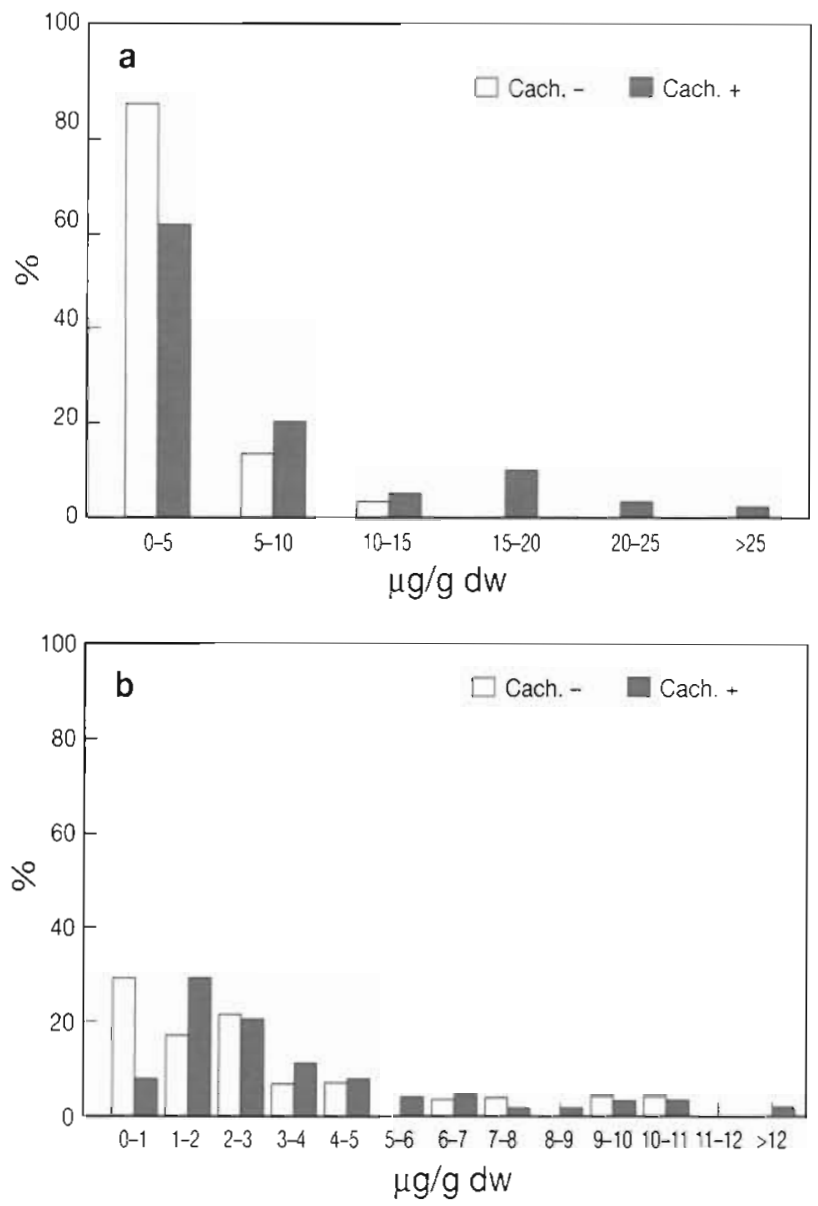

Fig. 3. Uria aalge. Relative distribution of $\mathrm{PCB}$ concentrations for non-cachectic (Cach. -) and cachectic (Cach. +) birds in (a) liver and (b) kidney of guillemots found dead on the Belgian coast

\section{CONCLUSIONS}

Oiling is a major cause of death for wintering guillemots in the southern North Sea: $55 \%$ of guillemots found on the Belgian shores showed evidence of external or internal oiling. However, a large majority of birds $(76 \%)$ were in a state of cachexia, probably due to shortage of food, bad weather conditions and natural disease. On the other hand, high levels of $\mathrm{Cu}, \mathrm{Zn}$, $\mathrm{Hg}$ and PCBs were clearly linked to cachexia, which can be considered as favourable to the development of lethal, acute, hemorrhagic gastro-enteropathy. None of these pollutants can be considered as the unique and direct cause of death, but might be an additional source of physiological stress, leading to debilitation and death. Further research is needed to determine the actual effects of stable pollutants on the health status of guillemots. The beaching of birds can be considered as a multifactorial response to numerous natural phenomena and a series of anthropogenic threats.

Acknowledgements. This study was supported by the 'Impulse Programme in Marine Sciences supported by the Belgian state-The Prime Minister's Services-Scientific, Technical and Cultural Affairs.' (MS/03/31, MS/12/032 and MS/12/033), by the 'European Commission' (13M/91/138, 1366-188901) and by The French Community of Belgium (no. 89/94-131). The authors thank P. Meire, H. Offringa, J. Seys, W. Roggeman, J Tavernier and the rehabilitation centres of Oostende, Nieuwpoort Blankenberge and Het Zwin for providing the specimens, and also R. Biondo and $M$. Bossicart for their valuable technical assistance. We also thank Professor A. Distèche for critical reading of the manuscript and M. Doyen for his assistance with the sorting and processing of raw data for statistical analyses.

Table 4. Uria aalge. Comparison of trace element concentrations ( $\mu \mathrm{g} \mathrm{g}^{-1} \mathrm{DW}$ ), expressed as a range of mean values or as a mean \pm standard deviation, in guillemots of different origins. Data from the Belgian coast given in bold. nd: non determined, <dl: below detection limit

\begin{tabular}{|c|c|c|c|c|c|c|c|}
\hline & Time & Place & $\mathrm{Cu}$ & $\mathrm{Zn}$ & $\mathrm{Cd}$ & Total Hg & Source \\
\hline \multicolumn{8}{|c|}{ Liver } \\
\hline $\mathrm{n}=51$ & 1970 to 1981 & Belgian coast & nd & nd & nd & $7.2 \pm 2.4$ & Delbeke et al. (1984) \\
\hline $\mathrm{n}=83$ & Apr to Nov 1988 & Northwest Scotland & $12.9-16.1$ & $58.4-69.7$ & $1.4-2.5$ & $0.9-3.7$ & Stewart et al. (1994) \\
\hline $\mathrm{n}=10$ & $\begin{array}{l}\text { Summer } \\
1992 \text { and } 1993\end{array}$ & $\begin{array}{l}\text { Hornoya: } \\
\text { North Norway }\end{array}$ & $20.0 \pm 2.9$ & $86.7 \pm 14.9$ & $3.1 \pm 1.1$ & $1.9 \pm 0.4$ & Wenzel \& Gabrielsen (1995) \\
\hline$n=143$ & Winter 1990 to 1995 & Belgian coast & $52 \pm 17$ & $145 \pm 39$ & $2.4 \pm 1.6$ & $6.1 \pm 3.4$ & This study \\
\hline \multicolumn{8}{|l|}{ Kidney } \\
\hline $\mathrm{n}=9$ & 1970 to 1981 & Belgian coast & nd & nd & nd & $4.4 \pm 1.7$ & Delbeke et al. (1984) \\
\hline $\mathrm{n}=10$ & $\begin{array}{l}\text { Summer } \\
1992 \text { and } 1993\end{array}$ & $\begin{array}{l}\text { Hornoyd, } \\
\text { North. Norway }\end{array}$ & $14.4 \pm 1.9$ & $114 \pm 13$ & $24.1 \pm 7.5$ & $1.5 \pm 0.2$ & Wenzel \& Gabrielsen (1995) \\
\hline $\mathrm{n}=83$ & Apr to Nov 1988 & Northwest Scotland & $12.3-15.2$ & $59.3-74.1$ & $1.6-11.7$ & $0.8-3.9$ & Stewart et al. (1994) \\
\hline $\mathrm{n}=143$ & Winter 1990 to 1995 & Belgian coast & $28 \pm 12$ & $169 \pm 41$ & $7.8 \pm 6.6$ & $4.6 \pm 2.9$ & This study \\
\hline \multicolumn{8}{|l|}{ Muscle } \\
\hline$n=24$ & Apr to Nov 1988 & Northwest Scotland & $10.2-14.0$ & $20.9-26.0$ & nd & $0.5-1.8$ & Stewart et d. (1994) \\
\hline $\mathrm{n}=10$ & $\begin{array}{l}\text { Summer } \\
1992 \text { and } 1993\end{array}$ & $\begin{array}{l}\text { Hornoyd, } \\
\text { North. Norway }\end{array}$ & $19.2 \pm 0.9$ & $49.3 \pm 3.3$ & $0.2 \pm 0.1$ & $0.4 \pm 0.1$ & Wenzel \& Gabrielsen (1995) \\
\hline $\mathrm{n}=143$ & Winter 1990 to 1995 & Belgian coast & $18 \pm 6$ & $60 \pm 14$ & $<\mathrm{dl}$ & $2.1 \pm 1.2$ & This study \\
\hline
\end{tabular}




\section{LITERATURE CITED}

Antoine N, Jansegers I, Holsbeek L, Jorris C, Bouquegneau, JM (1992) Contamination par les métaux lourds des oiseaux marins et des marsouins de la Mer du Nord. Bull Soc R Scj Ljège 61:163-176

Barnes H. Blackstock $J$ (1973) Estimation of lıpids in marine animals and tıssues: detailed investigation of the sulphosphovanullin method for 'total' lipıds. J Exp Mar Biol Ecol $12: 103-118$

Birkhead TR (1974) Movement and mortality rates of Britısh guillemots. Bird Study 21:241-254

Bouquegneau JM (1973) Etude de l'intoxication par le mercure d'un poisson téléostéen Anguilla anguilla. l Accumulation du mercure dans les organes. Bull Soc $R$ Sci Liège $9-10: 440-446$

Bouquegneau JM. Debacker V, Antoine N, Coignoul F, Holsbeek L, Jauniaux T, Tapia G, Joiris C (1994) Causes of mortality and heavy metals content of guillemots Uria aalge stranded along the Belgian Coast. Bull Soc R Sci Liège 63:211-217

Bouquegneau JM, Debacker V, Gobert S, Havelange S (1996) Role of metallothioneins in metal regulation by the guillemot Uria aalge. Comp Biochem Physiol 113 C:135-139

Bourne WRP, Vauk G (1988) Human impact upon North Sea birds. In: Salomons W, Bayne BL, Duursma EK, Forstner U (eds) Pollution of the North Sea-an assessment. Springer-Verlag, Heidelberg, p 579-595

Brosens L, Jauniaux T, Siebert U, Benke H, Coignoul F (1996) Observations of the helminths of harbour porpoises (Phocoena phocoena) and common guillemots (Uria alge) from the Belgian and German coasts. Vet Rec 139:254-257

Burger J, Gochfeld M (1995) Heavy metal and selenium concentrations in eggs of herring gulls (Larus argentatus): temporal differences from 1989 to 1994. Arch Environ Contam Toxicol 29:192-197

Camphuysen CJ (1995) Beached birds in the Netherlands as indicators of marine oil pollution. Sula 9:86-90

Camphuysen CJ, Leopold MF (1994) Atlas of seabirds in the southern North Sea. IBN Research Report 94/6, NIOZReport 1994-8. Institute for Forestry and Nature Research. Dutch Seabird Group and Netherlands Institute for Sea Research, Texel

Camphuysen CJ, van Franeker JA (1992) The value of beached bird surveys in monitoring marine oil pollution. Techn Rapp Vogelbescherming 10. Vogelbescherming Nederland, Zeist

Carter IC, Williams JM, Webb A, Tasker ML (1993) Seabird concentrations in the North Sea: an atlas of vulnerability to surface pollutants. Joint Nature Conservation Committee, Aberdeen

Dahlmann G, Timm D, Averbeck Chr, Camphuysen C, Skov H, Durinck J (1994) Oiled seabirds - comparative investigations on oiled seabirds and oiled beaches in the Netherlands, Denmark and Germany (1990-93). Mar Pollut Bull 28:305-310

Delbeke K, Joiris C, Decadt G (1984) Mercury contamination of the Belgian avifauna, 1970-1981. Environ Pollut Ser B Chem Phys 7:205-221

Dorrestein GM, van der Hage MH (1993) Diagnostic pathology. Proceedings of the European Conference of Avian Medecine and Surgery, Utrecht

Dorrestein GM, van der Hage MH (1997) Marine birds necropsy findings. In: Jauniaux $T$, Bouquegneau JM, Coignoul $F$ (ed) Marine mammals, seabirds, and pollution of marine systems. Presses de la Faculté de Médecine Vétérinaire de l'Université de Liège, Liège, p 151-165
Dunnet GM, Furness RW, Tasker ML, Becker PH (1990) Seabird ecology in the North Sea. Neth J Sea Res 26 $387-425$

Elliot JE, Scheuhammer AM, Leighton FA, Pearce PA (1992) Heavy metal and metallothionein concentrations in Atlantic Canadian seabirds. Arch Environ Contam Toxicol 22:63-73

Hatch RW, Ott WL (1968) Determination of sub-microgram quantities of mercury by atomic absorption spectrophotometry. Anal Chem 40:2085-2087

Jauniaux T, Brosens L, Farnir F, Manteca C, Losson B, Tavernier J, Vindevogel $H$, Coignoul $F$ (1996) Mortalité des oiseaux marins lors de l'hiver 1992-1993 le long du littoral belge. Ann Med Vet 140:149-159

Jauniaux T, Coignoul $F$ (1994) Aspergillose chez les olseaux marins échoués à la côte belge. Ann Med Vet 4:59-63

Kuyken E (1978) Beached bird surveys in Belgium. Ibis 120: $122-123$

Landsborough (1953) The migration of British Auk (Alcidae) as shown by the results of marking. Br Birds XLVI:3-15

Leighton FA (1993) The toxicity of oil petroleum to birds. Environ Rev 1:92-103

Lloyd C, Tasker ML, Partridge K (1991) The status of breeding seabirds in Britain and Ireland. T \& A.D. Poyser Ltd, London

Lock JW, Thompson DR, Furness RW, Bartle JA (1992) Metal concentrations in seabirds of the New Zealand region. Environ Pollut 75:289-300

Mead CJ (1974) The results of runging Auks in Britain and Ireland. Bird Study 21:45-87

Mead C, Balllie S (1981) Seabirds and oil: the worst winter Nature 292:10-11

Muirhead SJ, Furness RW (1988) Heavy metal concentrations in the tissues of seabirds from Gough Island, South Atlantic Ocean. Mar Pollut Bull 19:278-283

Nettleship DN, Evans PGH (1985) Distribution and status of the Alcidae. In: DN Nettleship. TR Birkhead (eds) The Atlantic Alcidae: the evolution, distribution and biology of the Auks inhabiting the Atlantic Ocean and adjacent water areas. Academic Press, London, p 84-88

North Sea Task Force Report (1993a) North Sea Subregion 4 assessment report (Netherlands, Belgium, France, Germany and United Kingdom). Oslo and Paris Commission. Olsen \& Olsen, Fredensborg

North Sea Task Force Report (1993b) North Sea quality status report. Oslo and Paris Commission. Olsen \& Olsen. Fredensborg

Ohlendorf HM, Fleming WJ (1988) Birds and environmental contaminants in San Francisco and Chesapeake Bays. Mar Pollut Bull 19:487-495

Peakall D (1992) Animals biomarkers as pollution indicators. Chapman \& Hall Ecotoxicology Series, London

Pionneau F (1987) Etudes des oiseaux marins échoués. Le Point Vétérinaire 19:469-478

Scheuhammer AM (1987) The chronic toxicity of aluminium, cadmium, mercury, and lead in birds: a review Environ Pollut 46:263-295

Stewart FM, Thompson DR, Furness RW, Harrisson N (1994) Seasonal variation in heavy metal levels in tissues of common guillemots, Uria aalge from Northwest Scotland. Arch Environ Contam Toxicol 27:168-175

Stowe TJ, Underwood LA (1984) Oil spillages affecting seabirds in the United Kingdom, 1966-83. Mar Pollut Bull 15:147-152

Thompson DR (1990) Metal levels in marine vertebrates. In: Furness RW, Rainbow PS (eds) Heavy metals in the marine environment. CRC Press, London, p 143-181 
Thompson DR, Furness RW, Barrett T (1992) Mercury concentrations in seabirds from colonies in the Northeast Atlantic. Arch Environ Contam Toxicol 23:383-389

Uthe JF, Solomon J, Grift B (1972) Metals and other elements. Rapid semimicro method for the determination of methylmercury in fish tissue. J Assoc Off Anal Chem 55: $583-589$

Responsible Subject Editor: O. Kinne, Oldendorf/Luhe, Germany
Walsh PM (1990) The use of seabirds as monitors of heavy metals in the marine environment. In: Furness RW, Rainbow PS (eds) Heavy metals in the marine environment. CRC Press, London, p 183-204

Wenzel C, Gabrielsen GW (1995) Trace element accumulation in three seabird species from Hornoya, Norway. Arch Environ Contam Toxicol 29:198-206

Manuscript first received: August 16, 1996 Revised version accepted: January 1, 1997 